\title{
How do diamonds grow in metal melt together with silicate minerals? An experimental study of diamond morphology
}

\author{
Aleksei Chepurov $^{1}$, Valery Sonin ${ }^{1}$, Jean-Marie Dereppe ${ }^{2}$, Egor Zhimulev ${ }^{1}$, and Anatoly Chepurov ${ }^{1}$ \\ ${ }^{1}$ Sobolev Institute of Geology and Mineralogy SB RAS, Koptyuga Ave. 3, Novosibirsk, 630090, Russia \\ ${ }^{2}$ University of Louvain, Place des Sciences 2, bte L6.06.01 à 1348 Louvain-la-Neuve, Belgium
}

Correspondence: Aleksei Chepurov (achepurov@igm.nsc.ru)

Received: 21 November 2019 - Published: 16 January 2020

\begin{abstract}
The origin and evolution of metal melts in the Earth's mantle and their role in the formation of diamond are the subject of active discussion. It is widely accepted that portions of metal melts in the form of pockets can be a suitable medium for diamond growth. This raises questions about the role of silicate minerals that form the walls of these pockets and are present in the volume of the metal melt during the growth of diamonds. The aim of the present work was to study the crystallization of diamond in a complex heterogeneous system: metal-melt-basalt-carbon. The experiments were performed using a multianvil high-pressure apparatus of split-sphere type (BARS) at a pressure of $5.5 \mathrm{GPa}$ and a temperature of $1500^{\circ} \mathrm{C}$. The results demonstrated crystallization of diamond in metal melt together with garnet and clinopyroxene, whose chemical compositions are similar to those of eclogitic inclusions in natural diamond. We show that the presence of silicates in the crystallization medium does not reduce the chemical ability of metal melts to catalyze the conversion of graphite into diamond, and, morphologically, diamond crystallizes mainly in the form of a cuboctahedron. When the content of the silicate material in the system exceeds $5 \mathrm{wt} \%$, diamond forms parallel-growth aggregates, but $15 \mathrm{wt} \%$ of silicate phases block the crystallization chamber, preventing the penetration of metallic melt into them, thus interrupting the growth of diamond. We infer that the studied mechanism of diamond crystallization can occur at lower-mantle conditions but could also have taken place in the ancient continental mantle of the Earth, under reducing conditions that allowed the stability of Fe-Ni melts.
\end{abstract}

\section{Introduction}

Natural diamond crystals are the best containers for storing and transporting material from great depths. Mineral inclusions in diamond may thus in many cases be indicators of the diamond crystallization environment. In lithospheric diamonds, the genesis of which is associated with mantle depths of less than $250 \mathrm{~km}$, inclusions of silicate minerals such as olivine, garnet, and pyroxene are common (Sobolev, 1977; Harris and Gurney, 1979; Gurney, 1989; Sobolev et al., 1973, 2004; Stachel and Harris, 2008). In most cases, these inclusions belong to the peridotite assemblage, although available data also indicate a significant role of inclusions of eclogitic assemblage (Gurney, 1984). Moreover, besides quantitative predominance, diamonds with peridotite inclusions are also the most ancient (Gurney et al., 2010). For super-deep, socalled sublithospheric diamonds, there is much less informa- tion, although these diamonds are increasingly attracting the interest of researchers (Stachel, 2001; Stachel et al., 2005; Kaminsky et al., 2009; Harte, 2010; Thomson et al., 2014; Pearson et al., 2014; Zedgenizov et al., 2016; Smith and Wang, 2017; Nestola, 2017; Nestola et al., 2018; Smith et al., 2018; Anzolini et al., 2018, 2019).

Metallic inclusions are a specific type of inclusion in natural diamonds from kimberlites (Sobolev et al., 1981; Meyer and McCallum, 1986; Vinokurov et al., 1998; Garanin and Kudryavtseva, 1990; Bulanova and Zayakina, 1991; Bulanova, 1995; Gorshkov et al., 1997; Bulanova et al., 1998; Stachel et al., 1998; Win et al., 2001; Hayman et al., 2005; Bulanova et al., 2010; Kaminsky and Wirth, 2011; Kaminsky, 2012; Kagi et al., 2016). These inclusions were found in lithospheric diamonds. The interest in the study of metallic inclusions significantly increased after their finding in large 
crystals of sublithospheric diamond, the so-called CLIPPIR diamonds (Smith et al., 2016), even if the relationship between metal melts and the genesis of natural diamond has been increasingly discussed (Smith and Kopylova, 2014; Smith et al., 2017). A characteristic feature of CLIPPIR diamonds is a variably light carbon isotopic composition, consistent with that of eclogitic diamonds and thought to result from the recycling of crustal carbon. The assumption that the carbon source for eclogitic diamonds is crustal material subducted to mantle depths seems quite possible, because the phenomenon of reduction of carbonate carbon to elemental carbon during subduction was proposed earlier (Malvoisin et al., 2012; Galvez et al., 2013) as well as demonstrated experimentally in the presence of metallic iron with the resulting graphite or diamond depending on pressure (Chepurov et al., 2011; Palyanov et al., 2013; Martirosyan et al., 2016).

The model of the diamond formation in the deep mantle is represented as the crystallization of diamonds in metalmelt pockets in host rocks (Smith et al., 2016). This raises questions about the role of silicate minerals in the process of crystallization of such diamonds - it is obvious that the evolving metal melts could interact in a certain way with the silicate rocks that enclose these metal pockets. Also, silicate minerals in the form of individual crystals and their aggregates were present in the volume of the metal melt during the dynamic evolution of metal pockets and directly during the growth of diamond crystals. Thus, many aspects still seem unclear about the crystallization medium of diamond, which is a complex heterogeneous system consisting of metal melts in which solid silicate phases are present. In this work, we studied synthetic diamond crystals and silicate minerals crystallized together in a metal-melt-basalt-carbon system. The main questions addressed were the transformation of the morphology of diamond crystals growing on a seed depending on the seed location in different zones of a reaction chamber, as well as the possibility of complete blocking of diamond growth through addition of various amounts of silicates to the system.

\section{Experimental methods}

The experiments were performed on a multianvil highpressure apparatus of split-sphere type (BARS) at the Institute of Geology and Mineralogy of the Siberian Branch of the Russian Academy of Sciences in Novosibirsk according to state assignment 0330-2016-0012. As the highpressure cells, containers made from a mixture based on $\mathrm{ZrO}_{2}$ were used. The rectangular parallelepiped pressure cells were $20 \mathrm{~mm} \times 20 \mathrm{~mm} \times 23 \mathrm{~mm}$ in size and had truncated edges and vertices. The tube-shaped heater was made of graphite. As electrical contacts in the cell, parts made of molybdenum were used. The pressure in the cell was calibrated at room temperature with the reference substances Bi and PbSe (Turkin, 2003, 2004). Temperature was mea- sured with a $\mathrm{PtRh}_{30}-\mathrm{PtRh}_{6}$ thermocouple without a pressure correction. The temperature correction for pressure was determined by the melting curve of pure $\mathrm{Ag}$ and $\mathrm{Au}$ (Tonkov and Ponyatovsky, 2004). The measurement error is $+0.2 \mathrm{GPa}$ and $+25^{\circ} \mathrm{C}$. Heating of the samples was performed after pressurization, and after the experiment the samples were cooled by quenching. Further experimental details with photographs are available in Chepurov et al. (2010), Zhimulev et al. (2012), and Tomilenko et al. (2015).

An experimental study of diamond crystallization in model systems was performed using several configurations of high-pressure cell assembly (Fig. 1a-d). The carbon source (graphite) was placed in the central, highertemperature zone, and the metal-silicate charge and the diamond seed crystals were placed above or below it. The choice of the configurations made it possible to study the crystallization of diamond on the seeds, located in different parts of the reaction volume, and to evaluate the effect of the initial arrangement of silicate additives on their capture by the growing diamond crystal and on the change of diamond morphology. A synthetic diamond mesh with a crystal size of $0.3 \mathrm{~mm}$ was chosen for the seed crystals. The metal component of the sample was a mixture of carbonyl iron and nickel in a mass ratio of $36: 64$. The silicate additive to the metal mixture was a fine-grained $(5 \mu \mathrm{m})$ powder of natural alkaline basalt glass (wt \%): $\mathrm{SiO}_{2}, 46.60 ; \mathrm{TiO}_{2}, 2.24 ; \mathrm{Al}_{2} \mathrm{O}_{3}, 15.27 ; \mathrm{Fe}_{2} \mathrm{O}_{3}, 4.82$; $\mathrm{FeO}, 6.38 ; \mathrm{MnO}, 0.15 ; \mathrm{CaO}, 6.68 ; \mathrm{MgO}, 4.25 ; \mathrm{NaO}, 6.14$; $\mathrm{K}_{2} \mathrm{O}, 4.70 ; \mathrm{P}_{2} \mathrm{O}_{5}, 2.34$; LOI, 0.1; total, 99.67. According to our planning of the experiment, at the chosen $P-T$ parameters the basalt forms an eclogitic mineral assemblage.

The experiments were carried out at a pressure of $5.5 \mathrm{GPa}$ and a temperature of $1500^{\circ} \mathrm{C}$, i.e., within the diamond stability field (Day, 2012), for a duration of $72 \mathrm{~h}$. Such a duration was chosen in order to grow diamond single crystals weighing up to 0.5 carat, which are evidence of the crystallization of diamond macrocrystals. Basalt was added to each experiment in amounts of $1 \mathrm{wt} \%-15 \mathrm{wt} \%$. Samples after experiments were extracted from the cell, and the metallic component was dissolved in acids.

The surface morphology of the obtained diamond crystals was investigated using optical (MC2-Zoom, Olympus BX35) and scanning electron microscopy (1540 XB Crossbeam, Carl Zeiss), as well as confocal laser scanning microscopy (LSM 800MAT, Carl Zeiss) in CKP "Nanostruktury" (Novosibirsk, Russia). The chemical composition of the mineral phases was determined using a MIRA LMU scanning electron microscope and a JEOL JXA-8100 microanalyzer. The measurements were carried out at an accelerating voltage of $15-20 \mathrm{kV}$, a probe current of $20-50 \mathrm{nA}$, and a counting time of 10-60 s. To determine the composition of homogeneous phases, a probe with a minimum spot diameter of about $3 \mu \mathrm{m}$ was used. To determine the average composition of the phase mixture, a defocused probe with a diameter of 20 to $100 \mu \mathrm{m}$ was used (depending on the grain size in the mixture). 


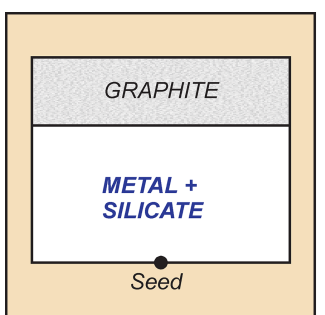

(a)

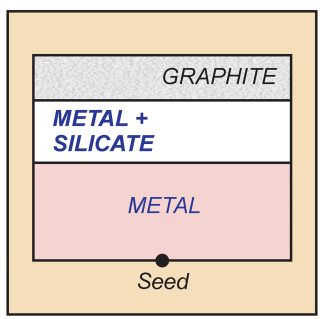

(b)

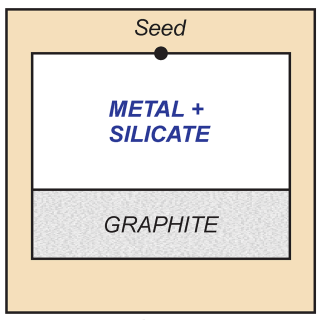

(c)

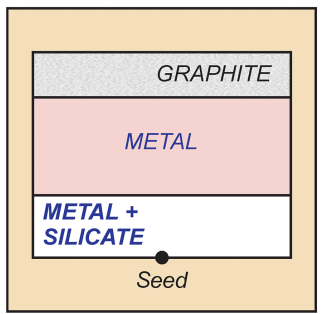

(d)

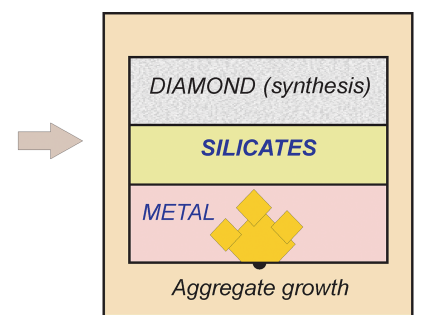

(e)

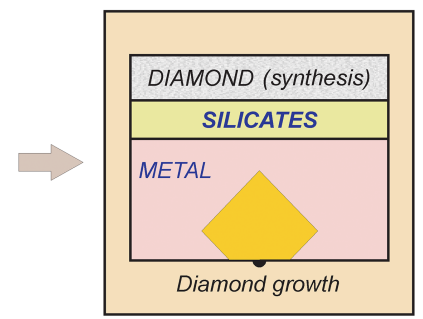

(f)

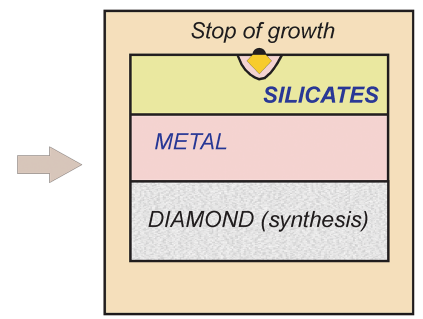

(g)

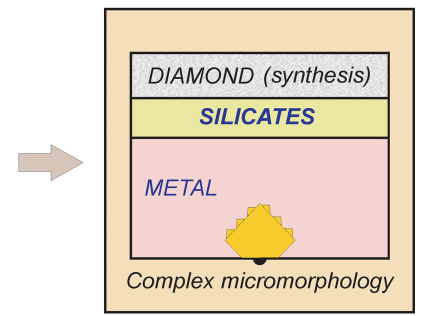

(h)
Figure 1. Schematic vertical cross sections of high-pressure sample assembly configurations used in experiments for diamond growth together with silicate minerals (a-d), and sketch drawing of the respective run products (e-h). (a) Basalt is evenly mixed with metal powder, and the diamond seed is located at the bottom of the chamber; (b) similar configuration but the lower part of initial metal does not contain basalt; (c) basalt is evenly mixed with metal powder, and the diamond seed is located at the top of the chamber; (d) the diamond seed is located at the bottom of the chamber and is covered with a thin layer of a mixture of metal and basalt - the rest of the sample is a basalt-free $\mathrm{Fe}-\mathrm{Ni}$ metal. Note that after experiments newly formed silicate phases were found mainly in the upper part of the chamber. Growth of diamond on a seed crystal occurred in the form of monocrystals (f), crystals of complex micromorphology with growth pyramids present on (111) faces (h), or as parallelgrowth aggregates (e). Only a little diamond growth was observed when the seed crystals were placed at the top of the chamber (g). For further explanation of run products the reader is referred to the Results section and to Table 1.
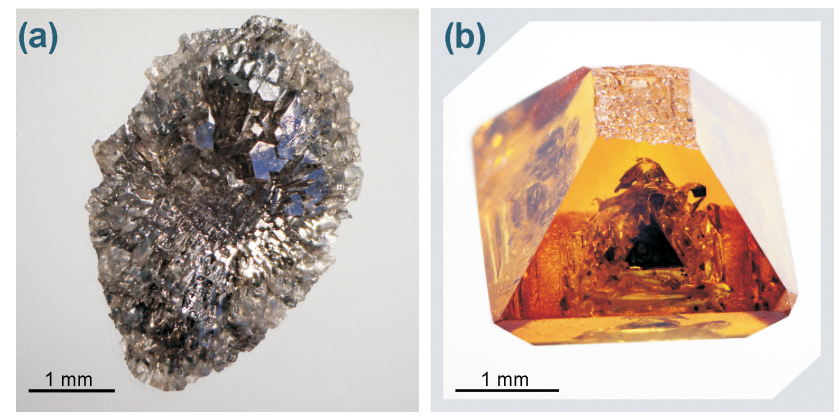

Figure 2. (a) General view of the carbon source residue after run 241 , which is a crystalline diamond aggregate; (b) diamond crystal weighing 0.5 carat from run $2-41$, grown in the $\mathrm{Fe}-\mathrm{Ni}-\mathrm{C}$ system with $1 \mathrm{wt} \%$ silicates added to the system (assembly configuration shown in Fig. 1a). The top of the crystal was in contact with the chamber wall and does not have faces. The crystal contains wellshaped inclusions of metal.

\section{Results}

The samples recovered at the end of experiments contained a quenched metal alloy, synthetic diamond, and synthetic silicates (Table 1). After dissolving the metal alloy, it was found that graphite at the source (Fig. 1e-h) completely turned into diamond (synthesis) and consisted of a finely crystalline diamond aggregate (Fig. 2a), with individual diamond grains $0.1-0.2 \mathrm{~mm}$ in size. The carbon source was partially dissolved and part of the carbon was transported to the growing seed crystal, which is a typical case for high-pressure, hightemperature (HPHT) processes.

Growth of a diamond on the seed crystals was observed in most experiments, primarily when the seeds were placed at the lower part of the assembly, and the added silicates were initially located at the upper part of the chamber (Fig. 1b). In this case (Fig. 1f) we observed the formation of diamond single crystals typical of diamonds grown in the $\mathrm{Fe}-\mathrm{Ni}-\mathrm{C}$ system. A more complicated situation was observed in experiments when the seed crystals were in contact with metal that initially contained a silicate component (Fig. 1a, d). In experiments with a silicate additive content of less than $5 \mathrm{wt} \%$, diamonds grown on the seeds were high-quality crystals of octahedral habit with the additional faces $\{110\},\{311\}$, and $\{100\}$ (Fig. 2b). The crystal faces were free of surface sculptures, and in rare cases dendritic and network sculptures were observed. The color of the diamond was yellow. When the content of silicates in the system was $5 \mathrm{wt} \%-10 \mathrm{wt} \%$, a number of specific features of the micromorphology of diamond crystals were observed. Growth pyramids with triangular forms, which have the same orientation as the triangle of the octahedral face, were found on diamond octahedral faces (Fig. 3a). The pyramids are faceted with stepped surfaces, most likely a trigon-trioctahedron. Measuring the profile of the pyramids by confocal laser scanning microscopy revealed that the vertical size of most of the pyramids was 
Table 1. Experimental conditions and run products.

\begin{tabular}{|c|c|c|c|c|c|c|c|c|}
\hline $\begin{array}{l}\text { Run } \\
\text { no. }\end{array}$ & $\begin{array}{c}P, \\
\mathrm{GPa}\end{array}$ & $\begin{array}{l}\mathrm{T}, \\
{ }^{\circ} \mathrm{C}\end{array}$ & $\begin{array}{l}\text { Duration, } \\
\text { hours }\end{array}$ & $\begin{array}{l}\text { Starting } \\
\text { sample }\end{array}$ & $\begin{array}{l}\text { Assembly } \\
\text { cofig.* }\end{array}$ & $\begin{array}{r}\text { Basalt } \\
\text { content** }\end{array}$ & $\begin{array}{l}\text { Run } \\
\text { products }\end{array}$ & $\begin{array}{l}\text { Morphology } \\
\text { of Dia } \mathrm{Gr}\end{array}$ \\
\hline $2-41$ & 5.5 & 1500 & 72 & $\mathrm{Fe}-\mathrm{Ni}, \mathrm{C}, \mathrm{Bas}$ & a & 1 & $\mathrm{Fe}-\mathrm{Ni}-\mathrm{C}, \mathrm{Dia}_{\mathrm{Syn}}, \mathrm{Dia}_{\mathrm{Gr}}$, Gar, Cpx & Crys \\
\hline $2-42$ & 5.5 & 1500 & 72 & $\mathrm{Fe}-\mathrm{Ni}, \mathrm{C}, \mathrm{Bas}$ & a & 3 & $\mathrm{Fe}-\mathrm{Ni}-\mathrm{C}, \mathrm{Dia}_{\mathrm{Syn}}, \mathrm{Dia}_{\mathrm{Gr}}$, Gar, Cpx & Crys \\
\hline $2-43$ & 5.5 & 1500 & 72 & $\mathrm{Fe}-\mathrm{Ni}, \mathrm{C}, \mathrm{Bas}$ & $\mathrm{a}$ & 5 & $\mathrm{Fe}-\mathrm{Ni}-\mathrm{C}, \mathrm{Dia}_{\mathrm{Syn}}, \mathrm{Dia}_{\mathrm{Gr}}$, Gar, Cpx & Crys + GPyr \\
\hline $2-44$ & 5.5 & 1500 & 72 & $\mathrm{Fe}-\mathrm{Ni}, \mathrm{C}, \mathrm{Bas}$ & a & 10 & $\mathrm{Fe}-\mathrm{Ni}-\mathrm{C}, \mathrm{Dia}_{\mathrm{Syn}}, \mathrm{Dia}_{\mathrm{Gr}}$, Gar, Cpx & Agg \\
\hline $2-45$ & 5.5 & 1500 & 72 & $\mathrm{Fe}-\mathrm{Ni}, \mathrm{C}, \mathrm{Bas}$ & $\mathrm{a}$ & 15 & $\mathrm{Fe}-\mathrm{Ni}-\mathrm{C}, \mathrm{Dia}_{\mathrm{Syn}}, \mathrm{Dia}_{\mathrm{Gr}}$, Gar, Cpx & Agg \\
\hline $2-46$ & 5.5 & 1500 & 72 & $\mathrm{Fe}-\mathrm{Ni}, \mathrm{C}, \mathrm{Bas}$ & $\mathrm{b}$ & 10 & $\mathrm{Fe}-\mathrm{Ni}-\mathrm{C}, \mathrm{Dia}_{\mathrm{Syn}}, \mathrm{Dia}_{\mathrm{Gr}}, \mathrm{Gar}, \mathrm{Cpx}$ & Crys \\
\hline $2-47$ & 5.5 & 1500 & 72 & $\mathrm{Fe}-\mathrm{Ni}, \mathrm{C}, \mathrm{Bas}$ & $\mathrm{b}$ & 15 & $\mathrm{Fe}-\mathrm{Ni}-\mathrm{C}, \mathrm{Dia}_{\mathrm{Syn}}, \mathrm{Dia}_{\mathrm{Gr}}$, Gar, Cpx & Crys + GPyr \\
\hline $2-48$ & 5.5 & 1500 & 72 & $\mathrm{Fe}-\mathrm{Ni}, \mathrm{C}, \mathrm{Bas}$ & $\mathrm{c}$ & 5 & $\mathrm{Fe}-\mathrm{Ni}-\mathrm{C}, \mathrm{Dia}_{\mathrm{Syn}}, \mathrm{Dia}_{\mathrm{Gr}}$, Gar, Cpx & Agg \\
\hline $2-49$ & 5.5 & 1500 & 72 & $\mathrm{Fe}-\mathrm{Ni}, \mathrm{C}, \mathrm{Bas}$ & $\mathrm{c}$ & 10 & $\mathrm{Fe}-\mathrm{Ni}-\mathrm{C}, \mathrm{Dia}_{\mathrm{Syn}}, \mathrm{Dia}_{\mathrm{Gr}}, \mathrm{Gar}, \mathrm{Cpx}$ & Agg \\
\hline $2-50$ & 5.5 & 1500 & 72 & $\mathrm{Fe}-\mathrm{Ni}, \mathrm{C}, \mathrm{Bas}$ & $\mathrm{c}$ & 15 & Fe-Ni-C, Diasyn, Gar, Cpx & No growth \\
\hline $2-51$ & 5.5 & 1500 & 72 & $\mathrm{Fe}-\mathrm{Ni}, \mathrm{C}, \mathrm{Bas}$ & d & 5 & $\mathrm{Fe}-\mathrm{Ni}-\mathrm{C}, \mathrm{Dia}_{\mathrm{Syn}}, \mathrm{Dia}_{\mathrm{Gr}}, \mathrm{Gar}, \mathrm{Cpx}$ & Crys + GPyr \\
\hline $2-52$ & 5.5 & 1500 & 72 & $\mathrm{Fe}-\mathrm{Ni}, \mathrm{C}, \mathrm{Bas}$ & d & 10 & $\mathrm{Fe}-\mathrm{Ni}-\mathrm{C}, \mathrm{Dia}_{\mathrm{Syn}}, \mathrm{Dia}_{\mathrm{Gr}}$, Gar, Cpx & Agg \\
\hline
\end{tabular}

$\mathrm{Fe}-\mathrm{Ni}$ - initial $\mathrm{Fe}_{0.36} \mathrm{Ni}_{0.64}$ powder; $\mathrm{C}$ - initial graphite source; Bas - basalt powder; $\mathrm{Fe}-\mathrm{Ni}-\mathrm{C}$ - metal melt; Diasyn - diamond synthesis in source; Dia $\mathrm{Gr}$ - diamond growth on seed; Gar - garnet; Cpx - clinopyroxene; Crys - diamond monocrystal; Crys + GPyr - diamond monocrystal with growth pyramids; Agg - parallel-growth aggregate of diamonds. * Assembly configuration according to Fig. 1. ** Content of basalt in metal-basalt mixture only, according to assembly configuration shown in Fig. 1 (wt \%).

in the range $1-3 \mu \mathrm{m}$ (Fig. 3b, c). Many such pyramids were often observed on the octahedral faces (Fig. 3d), and also numerous caverns were present which had well-cut contours (Fig. 3e). This effect was characteristic to varying degrees for all diamonds grown on the seed crystals from experiments with silicate content greater than $5 \mathrm{wt} \%$.

In experiments with the seed crystals located at the bottom of the chamber (Fig. 1a), and when the content of the silicate component in the metal reached $10 \mathrm{wt} \%-15 \mathrm{wt} \%$, diamond crystals grown on the seeds had a very complex surface relief and in most cases formed a parallel-growth aggregate of numerous individuals (Fig. 4). On the surface of diamonds from these experiments, the presence of a silicate material in the form of fine-grained, light-colored aggregates was observed, which filled the interstices between individuals (Fig. 5a). An important observation was noted for experiments with the seed crystals placed at the top of the chamber (Fig. 1c): in most cases, with the addition of silicates to the system, it was not possible to grow a representative diamond crystal on the seeds, but often with only a little growth observed (Fig. 1g), and with the addition of $15 \mathrm{wt} \%$ of silicate material, no growth of diamond on the seeds occurred.

Grown diamonds often contained dark faceted inclusions typical of diamonds produced in the $\mathrm{Fe}-\mathrm{Ni}-\mathrm{C}$ system (Fig. 2b). Another type of inclusions was identified in diamonds which is completely nontypical for crystals grown in metal-carbon systems, namely aggregates of numerous fine-grained phases (Fig. 5b, c). These inclusions have lightgray color. The typical size of individual aggregates is 100$200 \mu \mathrm{m}$ (Fig. 5c). These aggregates are most often elongated along the octahedron growth sector of diamond, passing through almost the entire crystal (Fig. 5b). It has often been observed that these inclusions reached the surface of diamond - in this place a cavernous area was observed, filled with light-gray material (Fig. 5d), similar to what is found on the surface of diamond between individuals (Fig. 5a).

The silicate phases after the experiments were found mainly in the upper part of the sample. It was a finegrained aggregate which consisted of garnet and clinopyroxene (Fig. 6). Small drops of quenched metal were observed between grains of the silicate minerals (Fig. 6b). Representative chemical analyses are shown in Tables 2 and 3. The synthesized silicates are characterized by stable compositions, and we found no significant difference in the chemical composition of minerals crystallized in experiments with different amounts of basalt added to the system. Clinopyroxene is characterized by a high content of sodium (up to $9.82 \mathrm{wt} \%$ $\left.\mathrm{Na}_{2} \mathrm{O}\right)$ and potassium $\left(0.14 \mathrm{wt} \%-0.31 \mathrm{wt} \% \mathrm{~K}_{2} \mathrm{O}\right)$. An impurity of titanium $\left(0.91 \mathrm{wt} \%-1.42 \mathrm{wt} \% \mathrm{TiO}_{2}\right)$ is characteristic in pyroxene. The iron content in pyroxene is low $(5.37 \mathrm{wt} \%-$ $7.48 \mathrm{wt} \% \mathrm{FeO})$. Garnet is characterized by a stable content of $\mathrm{CaO}$ and $\mathrm{FeO}, 11.01 \mathrm{wt} \%-14.75 \mathrm{wt} \%$ and $17.57 \mathrm{wt} \%-$ $23.27 \mathrm{wt} \%$, respectively. Garnet has low chromium content $\left(0.09\right.$ wt $\%-0.37$ wt $\left.\% \mathrm{Cr}_{2} \mathrm{O}_{3}\right)$ but a rather high titanium content that reaches $2.12 \mathrm{wt} \% \mathrm{TiO}_{2}$. It should be noted that increasing the silicate component did not change the composition of the final silicate phases: with an increase of the basalt addition to the initial charge varying from $1 \mathrm{wt} \%$ to $15 \mathrm{wt} \%$, the amount of silicates in the experimental products increased markedly, but their FeO content did not change. 

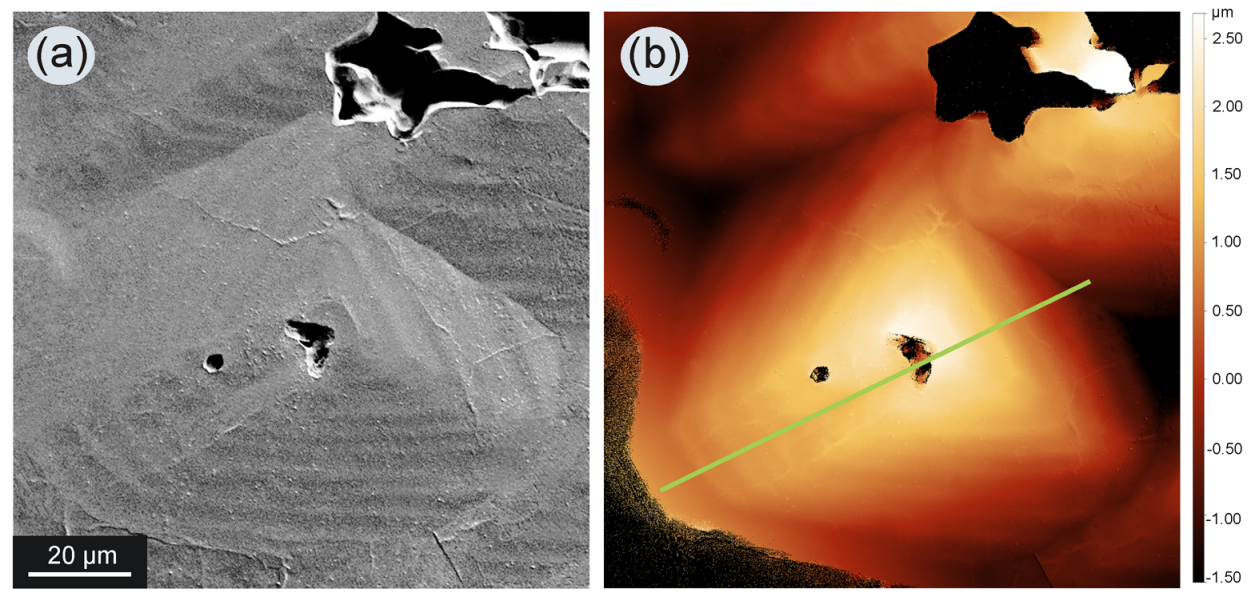

(c)
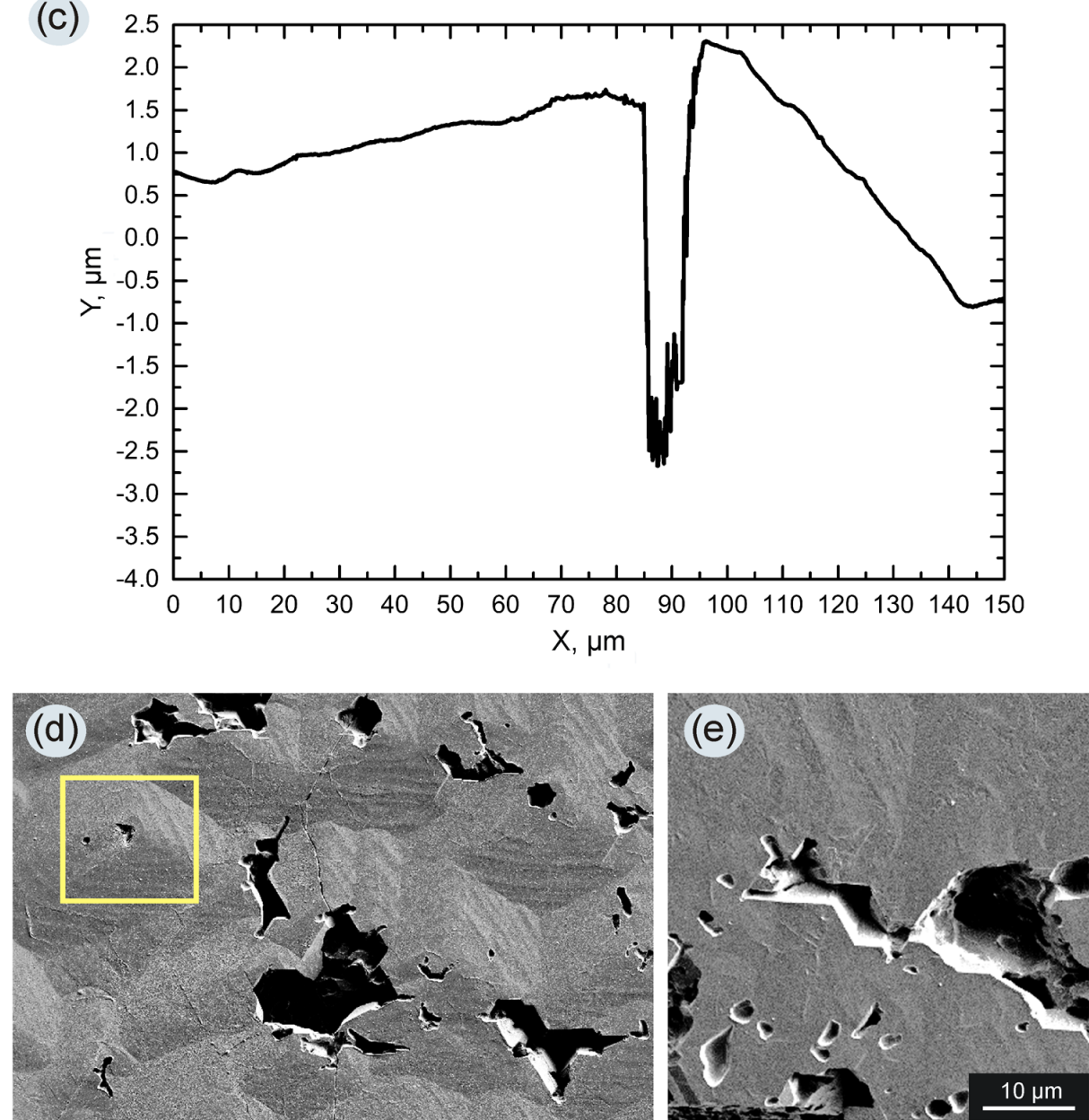

Figure 3. (a) SEM image of a growth pyramid on an octahedral face of diamond from run 2-51 with the addition of $5 \mathrm{wt} \%$ silicates (assembly configuration shown in Fig. 1d) - a cavern is present in the top of the pyramid; (b) relief of the pyramid shown in (a), measured by confocal laser scanning microscopy and the pyramid profile (c); (d) on (111) faces of the diamond, numerous pyramids are usually observed; the light-colored square indicates the pyramid that is shown in (a); (e) caverns on (111) diamond faces commonly have partially faceted edges. 
Table 2. Representative chemical analyses of garnet from the experiments.

\begin{tabular}{lrrrrrrrrrr}
\hline Sample & $2-41 / \mathrm{G} 1$ & $2-42 / \mathrm{G} 3$ & $2-43 / \mathrm{G} 1$ & $2-44 / \mathrm{G} 4$ & $2-45 / \mathrm{G} 2$ & $2-46 / \mathrm{G} 6$ & $2-47 / \mathrm{G} 3$ & $2-48 / \mathrm{G} 7$ & $2-49 / \mathrm{G} 5$ & $2-50 / \mathrm{G} 2$ \\
\hline $\mathrm{SiO}_{2}$ & 39.02 & 39.18 & 39.17 & 39.34 & 39.28 & 39.24 & 39.09 & 39.28 & 39.04 & 39.03 \\
$\mathrm{TiO}_{2}$ & 1.63 & 2.12 & 0.98 & 1.84 & 2.11 & 2.09 & 1.78 & 1.88 & 1.50 & 1.69 \\
$\mathrm{Al}_{2} \mathrm{O}_{3}$ & 20.01 & 20.05 & 20.83 & 19.37 & 19.09 & 19.49 & 19.76 & 19.86 & 19.57 & 20.55 \\
$\mathrm{Cr}_{2} \mathrm{O}_{3}$ & 0.37 & 0.25 & 0.35 & 0.29 & 0.18 & 0.09 & 0.16 & 0.33 & 0.29 & 0.12 \\
$\mathrm{FeO}$ & 20.94 & 17.57 & 19.15 & 19.54 & 20.66 & 19.66 & 22.25 & 18.89 & 23.27 & 18.12 \\
$\mathrm{MnO}$ & 0.35 & 0.29 & 0.34 & 0.30 & 0.35 & 0.30 & 0.29 & 0.31 & 0.31 & 0.30 \\
$\mathrm{MgO}$ & 5.21 & 5.66 & 6.22 & 4.45 & 5.33 & 5.26 & 4.85 & 5.83 & 4.76 & 5.84 \\
$\mathrm{CaO}$ & 12.04 & 14.51 & 12.83 & 14.75 & 12.86 & 13.55 & 11.71 & 13.32 & 11.01 & 14.05 \\
$\mathrm{Total}$ & 99.57 & 99.63 & 99.87 & 99.88 & 99.86 & 99.68 & 99.89 & 99.70 & 99.75 & 99.70 \\
\hline $\mathrm{Si}$ & 3.025 & 3.010 & 3.006 & 3.044 & 3.041 & 3.033 & 3.034 & 3.023 & 3.044 & 2.998 \\
$\mathrm{Ti}$ & 0.095 & 0.122 & 0.057 & 0.107 & 0.123 & 0.121 & 0.104 & 0.109 & 0.088 & 0.098 \\
$\mathrm{Al}$ & 1.828 & 1.815 & 1.884 & 1.767 & 1.742 & 1.776 & 1.808 & 1.802 & 1.799 & 1.860 \\
$\mathrm{Cr}$ & 0.023 & 0.015 & 0.021 & 0.018 & 0.011 & 0.006 & 0.010 & 0.020 & 0.018 & 0.007 \\
$\mathrm{Fe}$ & 1.358 & 1.129 & 1.229 & 1.265 & 1.338 & 1.271 & 1.444 & 1.216 & 1.517 & 1.164 \\
$\mathrm{Mn}$ & 0.023 & 0.019 & 0.022 & 0.020 & 0.023 & 0.020 & 0.019 & 0.020 & 0.020 & 0.020 \\
$\mathrm{Mg}$ & 0.602 & 0.648 & 0.712 & 0.513 & 0.615 & 0.606 & 0.561 & 0.669 & 0.553 & 0.669 \\
$\mathrm{Ca}$ & 1.000 & 1.194 & 1.055 & 1.223 & 1.067 & 1.122 & 0.974 & 1.098 & 0.920 & 1.156 \\
$\mathrm{Total}$ & 7.954 & 7.953 & 7.985 & 7.956 & 7.960 & 7.955 & 7.953 & 7.957 & 7.960 & 7.971 \\
\hline $100 \mathrm{Fe} \#$ & 69.28 & 63.52 & 63.33 & 71.13 & 68.50 & 67.71 & 72.02 & 64.51 & 73.28 & 63.51 \\
\hline
\end{tabular}

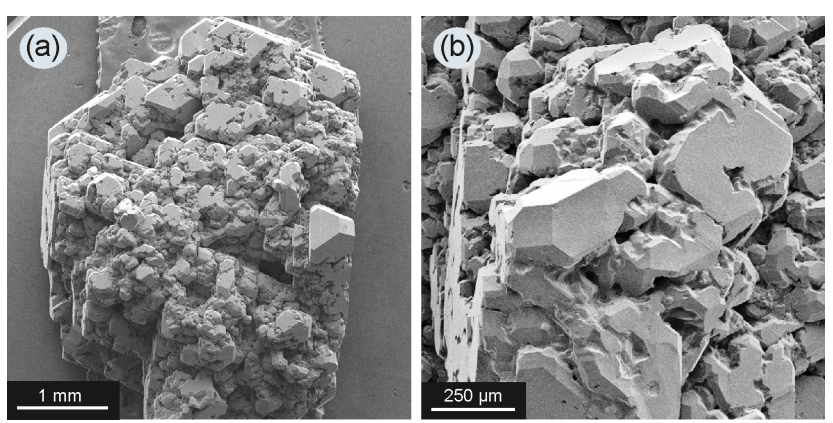

Figure 4. Diamond crystal grown in the $\mathrm{Fe}-\mathrm{Ni}-\mathrm{C}$ system with the addition of $10 \mathrm{wt} \%$ silicates (run 2-44, assembly configuration shown in Fig. 1a): (a) while maintaining the appearance of an octahedral crystal, the diamond grew as a parallel aggregate of numerous individuals; (b) enlarged fragment of the same crystal - each diamond subindividual has numerous faceted caverns on its faces.

\section{Discussion}

\subsection{Morphology of diamond crystals grown on seed crystals in a metal melt together with silicate minerals}

The experiments performed demonstrated the crystallization of diamond in the metal-carbon system together with silicate minerals. During the first minutes of the experiment, in the diamond $P-T$ stability field, graphite in the source turned into diamond (synthesis), i.e., there was homogeneous nucleation (Giardini and Tydings, 1962). Next, the process of crystallization of diamond on a seed crystal began (heteroge- neous nucleation), where the driving force is the temperature gradient in the pressure cell, in other words, the concentration of carbon in metal melt. In most cases, diamonds grown on the seeds have an octahedral habit with additional faces of a cube typical for crystals grown in metal-carbon systems. This is very important because it shows that, in metal melts in which various silicate components are present, morphologically typical octahedral crystals may grow.

Meanwhile, our study showed a number of specific macroand micromorphological features characteristic of diamonds grown in the presence of silicates in the system. Diamond crystals have flat faces only in experiments with small additions of silicate components to the system, sometimes with dendritic and network sculptures which are well-known for diamonds synthesized in metal-carbon systems (Tolansky, 1962; Kanda et al., 1980; Field, 1992). Such sculptures on diamond faces are imprints of metal phases which crystallize as the metal melt cools.

The effect of silicate components on the morphology of diamond crystals starts to appear when their amount is $5 \mathrm{wt} \%$ in the crystallization medium. In the first stage, we observed growth of pyramids with triangular forms having the same orientation as the triangle of the octahedral face (Fig. 3). Even at this initial stage, the face of a diamond acquires a relief with an average height of more than $3 \mu \mathrm{m}$ (Fig. 3c), whereas high-quality as-grown synthetic HPHT diamond crystals usually have a surface roughness of less than $5 \mathrm{~nm}$ (Chepurov et al., 2018a). Since several such pyramids formed on the faces of the crystal, after a certain time of growth, the face of a diamond crystal splits into several seg- 

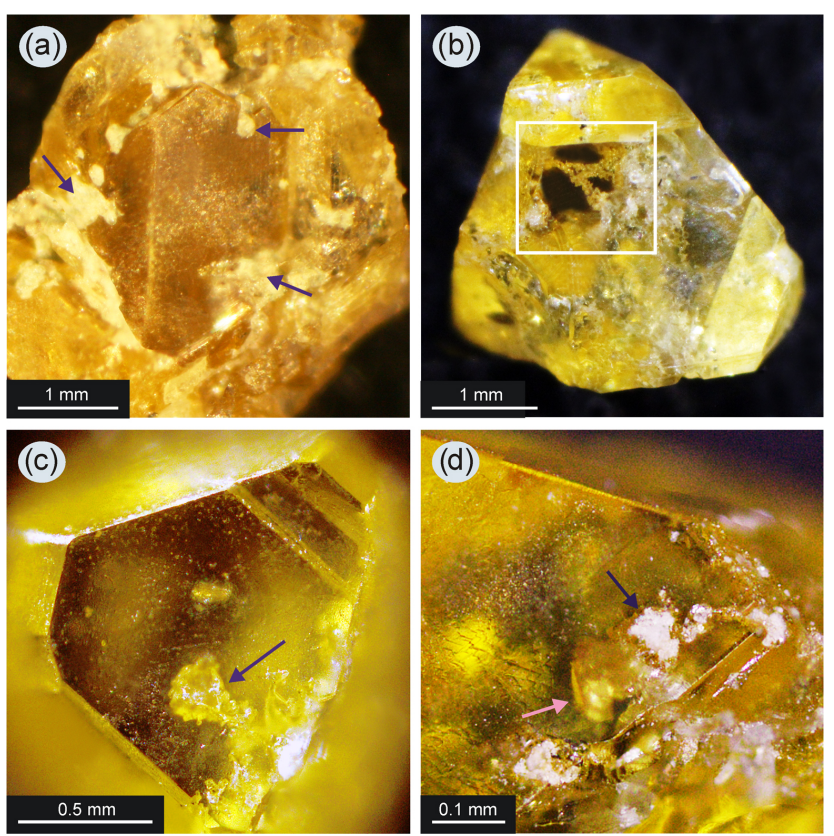

Figure 5. Diamond crystals with silicate inclusions: (a) part of a diamond crystal from a parallel-growth aggregate (run 2-44) - darkcolored arrows indicate the silicates in the form of fine-grained, light-colored aggregates that are intergrown with the diamond on its surface; silicates also fill the interstices between the diamond individuals; (b) diamond crystal of octahedral habit (run 2-43) - the white square shows a window where the chains of fine-grained silicate aggregates are visible inside the crystal; (c) the dark-colored arrow shows the inclusion of silicates of rounded shape consisting of a fine-grained aggregate; the inclusion is located close below the surface of the (111) diamond face (run 2-42); (d) silicate inclusion (shown by the light-colored arrow) that is not completely overgrown by diamond in run $2-42$ and has a specific appearance on the surface in the form of cavities filled with light-colored fine-grained material (shown by dark arrow).

ments corresponding to individual pyramids. Thus, the formation of individual pyramids on the facets of crystals is associated with the occurrence of independent centers for new growth layers. Further growth of single crystals became impossible, and several subindividuals formed on the initial diamond are further developed into a parallel-growth aggregate (Fig. 4). Such diamonds were often observed in our experiments.

The results of the experiments were largely affected by the type of assembly we used. When the diamond seed crystal was placed at the bottom of the chamber, and the basalt powder was present only in the upper part (Fig. 1b), diamond monocrystals acquire a complicated morphology only when the diamond had reached the upper zone where silicates were present. When the seed diamond was located in the upper part of the reaction volume (Fig. 1c), diamond crystals with a significant amount of defects and the complicated morphology began to form even with the addition of small amounts of silicates in the mixture. Due to differences in density and insignificant solubility in the metal melt, the silicates in the experiments float to the top of the chamber and shield the surface of growing diamond crystals. Diamond growth on the seeds was almost completely stopped at a content of $15 \mathrm{wt} \%$ of silicates in the system.

Comparing the crystals synthesized in experiments with natural diamonds, the following can be noted. It is known that the octahedral faces of natural diamonds commonly have a so-called polycentric structure of faces. It is believed that this sculpture is the result of the appearance of several growth centers on the face of a crystal (Bartoshinsky and Kvasnitsa, 1991). A similar phenomenon took place in our experiments; however, unlike the typical surface sculpture above composed of parallel triangular protrusions, separate growth pyramids with stepped side surfaces were present on diamonds grown in our experiments. Similar growth pyramids with triangular shapes were found on octahedral faces of natural diamond crystals that did not experience or had very little dissolution (Sunagava et al., 1984; Van Enckevort, 1992). Their formation is associated with groups of screwtype dislocations and is considered as evidence of the spirallayer mechanism of their growth. It is likely that the capture of mechanical impurities by the crystal causes the appearance of stepped pyramids, and we observed, in the apex of each pyramid (Fig. 3a-c), the presence of a cavity with irregular contours, which is most likely the original location of the impurity on the diamond face. On the $\{111\}$ faces of synthetic diamonds, similar accessories are also noted (Shigley et al., 1987). Thus, it was experimentally demonstrated that the most intensive formation of growth pyramids occurs when diamond grows from metal melts in which silicon is present (Kanda and Ohsawa, 1996). We observed a similar phenomenon when silicate components were added to the metal system.

Parallel-growth aggregates of diamond crystals observed in our experiments are of particular interest because research on diamonds with complex morphology is almost absent in the literature. It has been known for a long time that parallelgrowth aggregates of crystals are commonly observed among diamonds from kimberlites (Fig. 7) (Orlov, 1963), but their genesis and crystallization conditions are still unclear. Our experiments suggest that in a complex heterogeneous system when diamond crystallizes from a metallic liquid, crystals with a very complex morphology can form, including parallel-growth aggregates of diamond similar to those found in nature.

\subsection{Silicate phases crystallized together with diamond in a $(\mathrm{Fe}-\mathrm{Ni})$ metal-carbon melt}

In the experiments performed, the newly formed silicate phases were found in the volume of the metal sample, on the surface of diamond crystals, and as inclusions in diamond. This means that when studying silicate phases from our ex- 
Table 3. Representative chemical analyses of clinopyroxene from the experiments.

\begin{tabular}{|c|c|c|c|c|c|c|c|c|c|c|}
\hline Sample & $2-41 / \mathrm{G} 1$ & $2-42 / \mathrm{G} 3$ & $2-43 / \mathrm{G} 1$ & $2-44 / \mathrm{G} 4$ & $2-45 / \mathrm{G} 2$ & $2-46 / \mathrm{G} 6$ & $2-47 / G 3$ & $2-48 / G 7$ & 2-49/G5 & $2-50 / \mathrm{G} 2$ \\
\hline $\mathrm{SiO}_{2}$ & 54.18 & 54.04 & 54.39 & 54.61 & 54.12 & 54.27 & 53.85 & 54.13 & 54.20 & 54.48 \\
\hline $\mathrm{TiO}_{2}$ & 1.05 & 1.11 & 0.94 & 1.06 & 1.04 & 1.16 & 1.30 & 1.42 & 0.96 & 0.91 \\
\hline $\mathrm{Al}_{2} \mathrm{O}_{3}$ & 15.58 & 13.67 & 14.47 & 14.79 & 15.60 & 15.31 & 14.37 & 16.28 & 15.21 & 14.89 \\
\hline $\mathrm{Cr}_{2} \mathrm{O}_{3}$ & 0.26 & 0.11 & 0.25 & 0.21 & 0.10 & 0.03 & 0.08 & 0.08 & 0.34 & 0.40 \\
\hline $\mathrm{FeO}$ & 6.13 & 7.48 & 7.37 & 6.43 & 6.49 & 6.29 & 6.56 & 5.37 & 6.32 & 6.75 \\
\hline $\mathrm{MnO}$ & 0.06 & 0.05 & 0.05 & 0.05 & 0.06 & 0.05 & 0.02 & 0.03 & 0.04 & 0.05 \\
\hline $\mathrm{MgO}$ & 4.46 & 4.87 & 4.44 & 4.63 & 4.43 & 4.46 & 4.87 & 4.03 & 4.39 & 4.34 \\
\hline $\mathrm{CaO}$ & 8.52 & 9.87 & 8.49 & 8.88 & 8.31 & 8.91 & 9.68 & 8.08 & 8.19 & 8.20 \\
\hline $\mathrm{Na}_{2} \mathrm{O}$ & 9.18 & 8.38 & 9.08 & 8.84 & 9.05 & 9.20 & 8.79 & 9.66 & 9.82 & 9.54 \\
\hline $\mathrm{K}_{2} \mathrm{O}$ & 0.31 & 0.17 & 0.19 & 0.31 & 0.14 & 0.20 & 0.18 & 0.23 & 0.16 & 0.16 \\
\hline Total & 99.73 & 99.75 & 99.67 & 99.81 & 99.34 & 99.88 & 99.70 & 99.31 & 99.63 & 99.72 \\
\hline $\mathrm{Si}$ & 1.937 & 1.948 & 1.955 & 1.953 & 1.940 & 1.939 & 1.936 & 1.934 & 1.943 & 1.952 \\
\hline $\mathrm{Ti}$ & 0.028 & 0.030 & 0.025 & 0.029 & 0.028 & 0.031 & 0.035 & 0.038 & 0.026 & 0.025 \\
\hline $\mathrm{Al}$ & 0.656 & 0.581 & 0.613 & 0.623 & 0.659 & 0.645 & 0.609 & 0.685 & 0.643 & 0.629 \\
\hline $\mathrm{Cr}$ & 0.007 & 0.003 & 0.007 & 0.006 & 0.003 & 0.001 & 0.002 & 0.002 & 0.010 & 0.011 \\
\hline $\mathrm{Fe}$ & 0.183 & 0.226 & 0.222 & 0.192 & 0.195 & 0.188 & 0.197 & 0.160 & 0.189 & 0.202 \\
\hline $\mathrm{Mn}$ & 0.002 & 0.002 & 0.002 & 0.002 & 0.002 & 0.002 & 0.001 & 0.001 & 0.001 & 0.002 \\
\hline $\mathrm{Mg}$ & 0.238 & 0.262 & 0.238 & 0.247 & 0.237 & 0.238 & 0.261 & 0.215 & 0.235 & 0.232 \\
\hline $\mathrm{Ca}$ & 0.326 & 0.381 & 0.327 & 0.340 & 0.319 & 0.341 & 0.373 & 0.309 & 0.315 & 0.315 \\
\hline $\mathrm{Na}$ & 0.636 & 0.586 & 0.633 & 0.613 & 0.629 & 0.637 & 0.613 & 0.669 & 0.682 & 0.663 \\
\hline K & 0.014 & 0.008 & 0.009 & 0.014 & 0.006 & 0.009 & 0.008 & 0.010 & 0.007 & 0.007 \\
\hline Total & 4.028 & 4.026 & 4.030 & 4.018 & 4.018 & 4.030 & 4.034 & 4.024 & 4.050 & 4.038 \\
\hline 100Fe\# & 43.54 & 46.28 & 48.22 & 43.79 & 45.11 & 44.17 & 43.04 & 42.78 & 44.68 & 46.60 \\
\hline
\end{tabular}
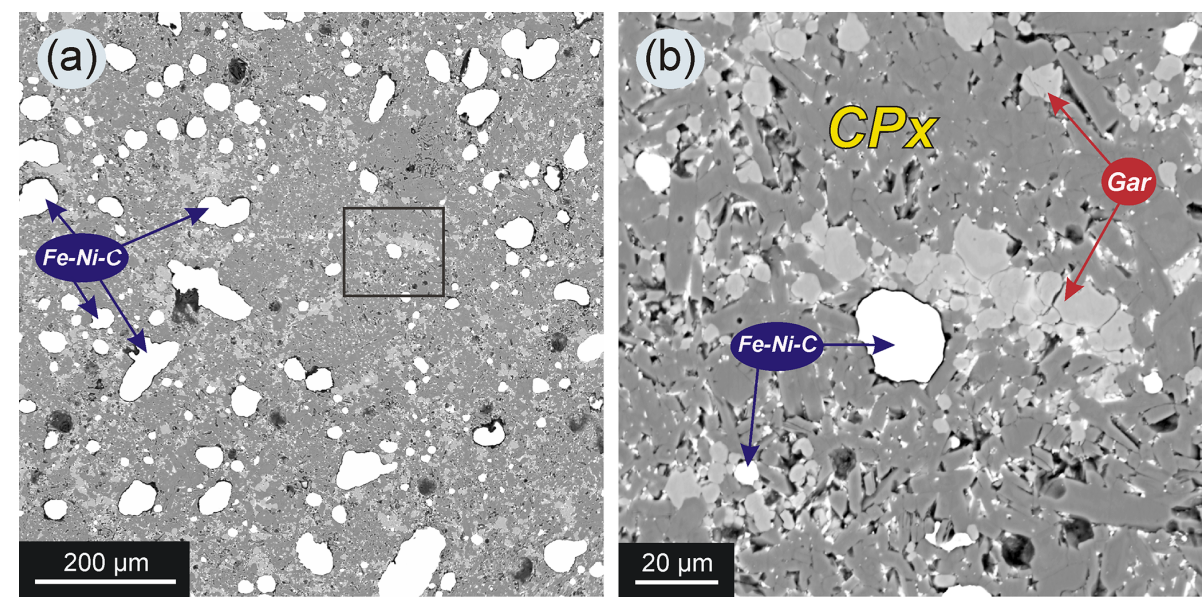

Figure 6. SEM images of synthetic silicates from the upper part of the chamber (assembly configuration as in Fig. 1f) from experiment 2-47 with $15 \mathrm{wt} \%$ basalt addition to the system: (a) general view, $\mathrm{Fe}-\mathrm{Ni}-\mathrm{C}$ - quenched metal (bright spots); (b) magnified view of area shown with a black square in (a) - silicates are represented by garnet (Gar) and clinopyroxene (Cpx). Note that metal drops in the silicate matrix are not interconnected.

periment, we need to understand if these minerals reflect the same conditions under which the diamond grew.

The process of formation of silicate minerals in our experiments is as follows. At the beginning of the experiments, basalt particles were present in the form of a uniformly distributed mass of fine-grained silicate substance in the volume of the metal mixture. At the high $P-T$ conditions of the experiments, the basaltic material recrystallized to form garnet and clinopyroxene. Due to the significant difference in density compared with the metal melt, the silicates gradually floated upward in the crystallization chamber. In this case, the aggregation of individual particles occurred, which then filled the upper part of the reaction chamber. The size of the individual grains of synthetic silicate minerals in ex- 

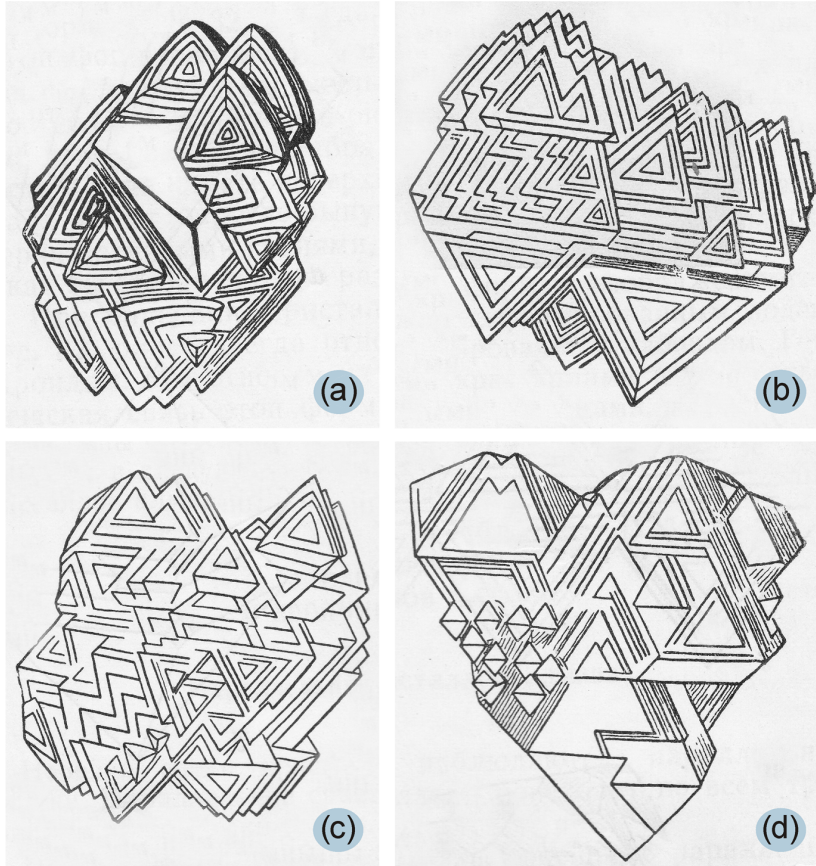

Figure 7. Parallel-growth aggregates of natural diamond crystals, original drawing from the book Morphology of diamond by Yu. L. Orlov (Orlov, 1963).

periments usually did not exceed $20 \mu \mathrm{m}$ (Fig. 6). However, these grains are larger than the original basalt particles of the starting powder $(5 \mu \mathrm{m})$. Often, the silicate aggregates present in the metal melt were captured by diamond crystals during growth, forming inclusions in diamond. The captured silicates can be considered as "synchronous" minerals with respect to diamond, possibly protogenetic, which is in good agreement with recent research (Nestola et al., 2017, 2019). Considering the specific appearance of the inclusion of silicates in our experiments, they can be easily distinguished by visual observation from the metal-catalyst inclusions that are dark colored and usually faceted (Fig. 2b) (Shigley et al., 1992, 1993).

With a small content of basalt in the initial mixture, silicates were present in the growth system rather as a mechanical impurity, affecting the changing morphology of the growing diamond, and the silicate phases themselves did not form representative samples. With a high content of silicate minerals in the system (more than $10 \mathrm{wt} \%$ ), the latter formed separate volumes of silicate substance, immiscible with the metal melt, which often blocked the growth of certain areas of diamond crystals. It is important to note that in this work we use wt $\%$, and, due to the significant difference in density between metal and silicates (more than 2 times), the volume of the silicate substance in the experiments was very significant. For example, in experiment 2-44 (Table 1) with $10 \mathrm{wt} \%$ basalt, the amount of silicate minerals was about $25 \mathrm{vol} \%$, with respectively $75 \mathrm{vol} \%$ of metal. However, di- amond under such conditions grew on the seed crystal at the bottom of the chamber, most likely because during the experiment these silicate aggregations floated upwards. At the upper sections of the chamber the silicates formed a solid layer with only a little metal present as drops with sizes from less than 5 to $200 \mu \mathrm{m}$. We extracted the representative samples of silicates precisely from such zones (Fig. 6). In these areas, obviously, the diamond could not grow. Diamond continued to grow where the metal melt was available around the crystal and where carbon was transported to the surface of the crystal.

Thus, the micro- and macromorphology of diamonds synthesized in our experiments (with silicate phases in the growth medium) largely reflect the model situation created under the experimental conditions in a very limited amount of metal melt. Under natural conditions, there is a wide variety of options. In our experiments, diamond growth occurred on the seed crystal fixed in the cell material - i.e., silicate phases moving in a metal melt could easily block its growth. In natural conditions it is more likely that diamond crystallization centers occur in the volume of the metal melt.

\subsection{Application to natural geological environments}

In order to transfer the results of our experiments to natural objects, we should refer to the latest data on the findings of metallic inclusions in large crystals of natural sublithospheric diamonds (Smith et al., 2016). The diamond crystallization process, according to the proposed hypothesis, is based on the formation and evolution of metal pockets which are formed during subduction. Such pockets are nothing but volumes of metal melt. In a first approximation, our high-pressure experimental cells also represent small volumes of metal melt in which carbon is present and diamond crystallization occurs. In this case, an important role could also be played by the fluid phase, which is always present in metal-carbon melts and is represented mainly by hydrocarbons (Zhimulev et al., 2015). Recent papers by Smith et al. $(2016,2018)$ discuss the presence of a fluid phase $\left(\mathrm{CH}_{4}\right)$ in inclusions in diamonds and consider diamond growth in the presence of metallic melt.

In our experiments, we artificially added silicate components to the system, simulating the immiscibility of the metal melt and silicate substance, and the silicate additives were small in size and evenly distributed in the volume of the metal melt. We can expect that in natural conditions, during the formation of metal pockets, the silicate substance will be mixed with a metal melt at certain times. An example would be the finding of polyphase inclusions with the simultaneous presence of silicate, carbonate, and sulfide components (Mikhno and Korsakov, 2015). At the same time, small particles of silicate minerals can behave in a similar way as in the experiment: the process of consolidation of individual silicate grains into larger aggregates will occur very quickly, while they will float upward in the metal melt. As a result, after a 


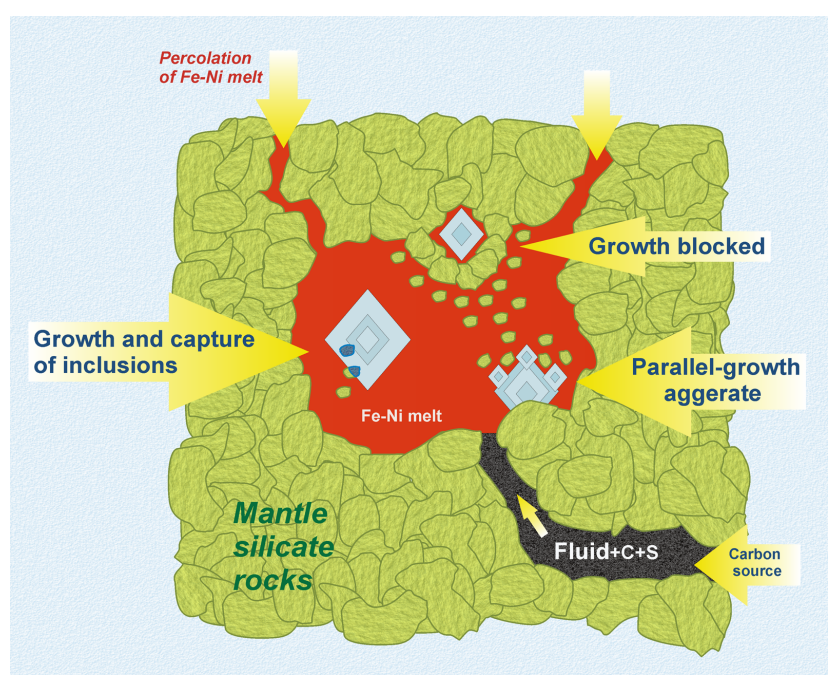

Figure 8. Scheme illustrating the growth of diamond crystals in metal melt pocket. Percolation of the Fe-Ni metal through silicate rock in the mantle (shown with arrows in the upper part) forms the metal pocket. Fluid could act as a transporter of carbon and other light elements, like sulfur, to the pocket. High-quality large diamond crystals can grow in the volume of the metal melt that is almost silicate-free (large crystal on the left); rare inclusions of silicate minerals, which are present together with diamond in the metal melt, can be captured by the crystal. Parallel-growth aggregates of diamond can form when there are many silicate phases in the metal around the growing diamond (crystal at the bottom). Diamond growth is completely interrupted by silicate minerals floating in the metal melt - such case is most likely to occur in the upper part of the pocket (small crystal at the top).

fairly short period of time, the metal pocket became silicatefree. In such conditions and with the presence of a carbon source, growth of high-quality diamond crystals which are almost free from inclusions of silicate minerals could occur. In certain areas of the pocket where diamond crystals are surrounded by a large amount of a silicate substance, diamond crystallization becomes much more complicated. It is important to emphasize that since chemically solid silicates interact neither with diamond nor with metal melt, the mechanical interaction of diamond and silicates will inevitably occur, resulting in the capture of silicate minerals in the form of inclusions, then the complication of the morphology of the growing facets of diamond, or such phenomena as the formation of parallel-growth aggregates (Fig. 8).

It seems quite possible that the size of the metal pockets in the Earth's mantle can be very large: judging by the findings of sublithospheric diamonds weighing several hundreds and thousands of carats (Scarratt and Shor, 2006; Smith et al., 2016), which are often only fragments of larger crystals, the size of evolving drops of metal melt in the Earth's mantle may reach gigantic sizes. In this case, the crystallization centers, i.e., diamond seed crystals, could occur in the volume of the metal, thus allowing for the growth of a diamond crystal in all directions. At the same time, the growth rates of natural diamonds can be much lower compared with model experiments. All this, ultimately, will lead to the formation of highquality octahedral diamond crystals with a small amount of inclusions. Changes in the chemical composition of the melt occurring in natural environments, carbon delay, or other factors will obviously affect the dynamics of diamond crystal growth in the metal melt, up to the interruption of growth and even dissolution of crystals - such processes are reflected in a complex zonation which is observed in almost every natural diamond crystal (Beskrovanov, 2000; Kaminsky and Khachatryan, 2004; Nasdala et al., 2005; Shirey and Shigley, 2013; Bulanova et al., 2017). Regarding the issue of stability and dissolution of diamond crystals, it is worth noting that the presence of silicate substances in a heterogeneous metalsilicate system can also contribute to the formation of complex diamond dissolution surfaces, which has been demonstrated experimentally (Chepurov et al., 2018b).

It is important to keep in mind that metal melts are sufficiently mobile liquids that can easily migrate under certain conditions (Fig. 8). It is believed that Fe melt can percolate through the silicate matrix if its amount exceeds $5 \mathrm{vol} \%$ (Yoshino et al., 2004). The critical amount of the metal melt fraction that forms a network is 6 vol \% for a dihedral angle of $60-85^{\circ}$. At the same time, it is estimated that the residual fractions of the metal melt (metal pockets) can reach 2 $5 \mathrm{vol} \%$ (Walte et al., 2011). There is another mechanism that contributes to the percolation of metal melts through the interstices in a silicate rock, and we have recently studied this effect experimentally (Zhimulev et al., 2018). This process will stimulate the evolution of metal pockets in the Earth's mantle. At the same time, the migrating metal melt is saturated with carbon and other light components, such as sulfur, forming a complex $\mathrm{Fe}-\mathrm{Ni}-\mathrm{C}-\mathrm{S}$ liquid in which diamond crystals can grow (Zhimulev et al., 2012). This fact is very interesting for mantle geology, because it demonstrates the growth of diamond from metal-sulfide melts. It is worth noting that sulfide inclusions are one of the most common in diamonds, especially in central areas of the crystals (Harris and Gurney, 1979; Bulanova et al., 1990).

Presenting the models of diamond crystallization and its capture of inclusions of silicates, oxides, sulfides, and metals during growth, one should take into account the possibility of transformation of these phases in postcrystallization conditions. So, after the completion of crystallization, diamonds for hundreds of millions and even billions of years were stored in the Earth's mantle. During this time, inclusions of silicates, oxides, and sulfides remained completely inert "prisoners" of diamond, which is confirmed by the experimental data (Fedorov et al., 2006). On the other hand, inclusions of metals at mantle $P-T$ conditions are able to move through the volume of a diamond crystal by recrystallization of the diamond substance, thereby reaching the surface of the crystal and leaving the diamond (Chepurov et al., 2000; Fedorov et al., 2005). Thus, this process of self-purification of 
diamond from inclusions of metal melts can serve as one of the explanations for the relatively rare findings of native iron inclusions in natural diamonds.

The mechanisms of crystallization of diamond and silicates discussed above are relevant in the general context of the Earth's evolution. It is known that most inclusions in natural lithospheric diamonds are of an ancient age (Gurney et al., 2010), and peridotitic inclusions reach an age of more than $3 \mathrm{Ga}$ (Richardson et al., 1984). During this period, the continental mantle was reduced, corresponding to the equilibrium of silicates with the Fe-Ni phase (Kadik et al., 2004), and for peridotite xenoliths the oxygen fugacity level is estimated to be close to the Fe-Ni melt stability line (Shirey et al., 2013). It is important to note that metal-carbon melts can be stable under more oxidized conditions than the corresponding solid metal phase; thus, diamonds in the $\mathrm{Fe}-\mathrm{Ni}-\mathrm{C}$ melt can crystallize even with wüstite (Fedorov et al., 2002). Therefore, if diamonds with inclusions of $\mathrm{Fe}-\mathrm{Ni}$ and $\mathrm{Fe}-\mathrm{Ni}-$ sulfides are considered as evidence of diamond growth with the participation of metal liquids under upper-mantle conditions, it can be assumed that the formation of such diamonds, as well as crystallization of coexisting silicate minerals, could occur precisely under the highly reduced conditions in the ancient mantle of the Earth where iron and nickel existed in the form of metal or metal-sulfide melts.

Silicate minerals in our experiments were formed in highly reduced conditions and consisted mainly of garnet and clinopyroxene. Clinopyroxene is characterized by a high $\mathrm{Na}$ content and garnet is a low-chromium variety with a high $\mathrm{Ca}$ content. Therefore, the chemical composition of the synthetic minerals is close to the typical inclusions of the eclogitic assemblage in natural diamonds, namely to omphacite clinopyroxene and grossular-pyrope-almandine garnet (Fig. 9). Eclogites are considered derivatives of subducting basalts, and, consequently, they pass a long and complex way deep into the planet. The role of subduction processes in the genesis of diamond is still insufficiently studied and little discussed in the literature, especially from the standpoint of understanding the role of $\mathrm{Fe}-\mathrm{Ni}$ and sulfide melts. It is known that $\mathrm{Fe}-\mathrm{Ni}$ sulfides (and even native iron) are usually present in diamond-bearing eclogites where these sulfide inclusions are more often present in the form of intermittent rims around diamond (Bulanova et al., 1990). The results of our experiments lead us to consider the possibility of crystallization of some diamonds during subduction at lithospheric-mantle conditions with the participation of metallic liquids. Confirmation of this can be the finding of inclusions of metals in diamonds, which cannot be classified as sublithospheric ones according to the whole set of features.

In later epochs, as planet Earth evolved, highly reduced conditions prevailed only in the deeper parts of the Earth. It is assumed that the formation of the metal phase begins at depths greater than $250 \mathrm{~km}$ (Frost and McCammon, 2008; Rohrbach et al., 2007, 2011). Smith et al. (2016) proposed a mechanism of diamond formation with the participation

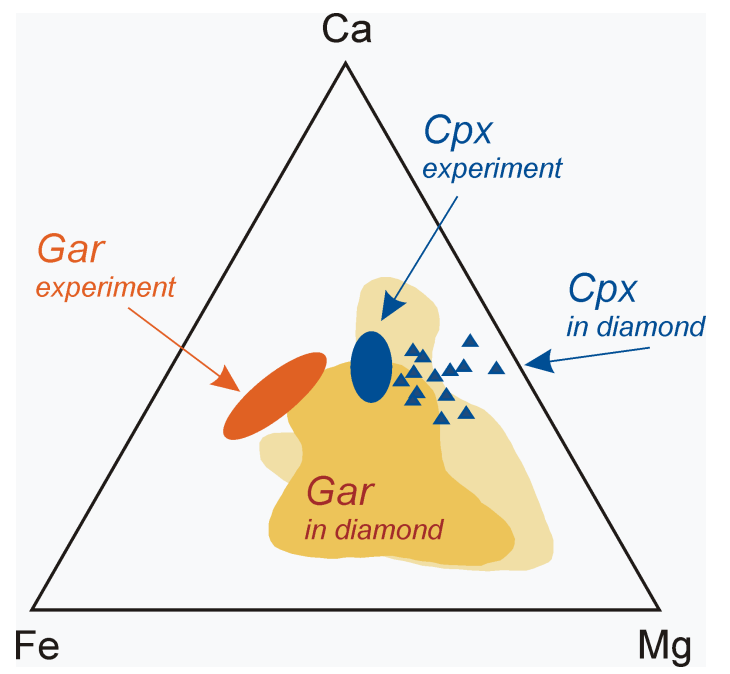

Figure 9. Chemical composition of synthetic garnet (oval-shape field "Gar experiment") and clinopyroxene (oval-shape field "Cpx experiment") of this study compared to silicate inclusions of eclogitic paragenesis in natural diamonds: grossular-pyropealmandine garnet ("Gar in diamond") and omphacite clinopyroxene (triangles). Data on natural samples are from Sobolev (1977), Harris and Gurney (1979), Davis et al. (2003), and Liu et al. (2009).

of metal liquids, suggesting the possibility of subduction of crustal material to the depths of the lower mantle where native metals and, accordingly, silicate minerals of higher pressures become stable. Highly reduced conditions at super depths of the Earth's mantle stimulate the crystallization of diamond in metal melts, which are stable under these conditions and are a favorable environment for the growth of high-quality and large diamond crystals. At the same time, diamond as an inclusion will capture silicate minerals that are typical for these depths. This process is probably happening now.

\section{Conclusions}

This experimental study on the joint crystallization of diamond in the presence of silicate minerals has shown that the presence of silicates in the crystallization medium does not reduce the chemical ability of metal melts to catalyze the conversion of graphite into diamond, and, morphologically, growth of diamond on seed crystals occurred mainly in the form of octahedra. A more difficult task was to grow high-quality diamond single crystals on the seeds in a heterogeneous system. The main effect of silicates on diamond growth in the metal-carbon system was the loss of morphological stability of the $\{111\}$ faces, which starts at $5 \mathrm{wt} \%$ of silicate substance in the crystallization medium. At a very high content in the system, the silicate phases completely block some areas of the crystallization chamber, preventing the penetration of the metal melt into them. In this case, the 
growth of a diamond crystal on the seeds stopped. Thus, the diamond growth in a complex heterogeneous environment, consisting of metal-carbon melt and silicate components, depends not only on temperature, pressure, and chemical composition of the system but largely on the transport capacity of the medium.

The present paper shows the process of crystallization of diamond in a metal melt together with garnet and clinopyroxene, whose chemical composition is similar to minerals of eclogites. This means that, under natural conditions, diamonds could grow in the pockets of metal melt surrounded by such silicate rock. In this case, a key factor for the progress of diamond growth will be the maintenance of highly reduced conditions in which the metal melt environment for crystallization of diamond exists. The described mechanism can occur not only in modern conditions in the deepest mantle but probably could have taken place in the ancient continental mantle of the Earth, which was reduced, corresponding to the equilibrium of silicates with a Fe-Ni melt.

Data availability. No data sets were used in this article.

Author contributions. AlC and VS designed and carried out the experiments. EZ performed microscopic studies. AlC, AnC, and J-MD prepared the paper with contributions from all coauthors.

Competing interests. The authors declare that they have no conflict of interest.

Acknowledgements. The authors thank three anonymous reviewers and editor Elisabetta Rampone for their detailed and constructive comments which greatly improved the manuscript.

Financial support. This research has been supported by the Russian Science Foundation (grant no. 17-17-01154).

Review statement. This paper was edited by Elisabetta Rampone.

\section{References}

Anzolini, C., Prencipe, M., Alvaro, M., Romano, C., Vona, A., Lorenzon, S., Smith, E. M., Brenker, F. E., and Nestola, F.: Depth of formation of super-deep diamonds: Raman barometry of $\mathrm{CaSiO}_{3}$-walstromite inclusions, Am. Mineral., 103, 69-74, https://doi.org/10.2138/am-2018-6184, 2018.

Anzolini, C., Nestola, F., Mazzucchelli, M. L., Alvaro, M., Nimis, P., Gianese, A., Morganti, S., Marone, F., Campione, M., Hutchison, M. T., and Harris, J. W.: Depth of diamond formation ob- tained from single periclase inclusions, Geology, 47, 219-222, https://doi.org/10.1130/G45605.1, 2019.

Bartoshinsky, Z. V. and Kvasnitsa, V. N. (Eds.): Crystallomorphology of diamond from kimberlites, Naukova Dumka, Kiev, 1991 (in Russian).

Beskrovanov, V. V.: Ontogeny of the diamond, Nauka, Novosibirsk, 2000 (in Russian).

Bulanova, G. P.: The formation of diamond, J. Geochem. Explor., 53, 1-23, https://doi.org/10.1016/0375-6742(94)00016-5, 1995.

Bulanova, G. P. and Zayakina, N. V.: Graphite - iron - cohenite assemblage in the central zone of diamond from 23rd Party Congress kimberlite, Dokl. Akad. Nauk SSSR, 317, 706-709, 1991 (in Russian).

Bulanova, G. P., Spetsius, Z. V., and Leskova, N. V. (Eds.): Sulfides in diamonds and in xenoliths from kimberlite pipes of Yakutiia, Nauka, Novosibirsk, 1990 (in Russian).

Bulanova, G. P., Griffin, W. L., and Ryan, G. G.: Nucleation environment of diamonds from Yakutian Kimberlites, Mineral. Mag., 62, 409-419, https://doi.org/10.1180/002646198547675, 1998.

Bulanova, G. P., Walter, M. J., Smith, C. B., Kohn, S. C., Armstrong, L. S., Blundy, J., and Gobbo, L.: Mineral inclusions in sublithospheric diamonds from Collier 4 kimberlite pipe, Juina, Brazil: Subducted protoliths, carbonated melts and primary kimberlite magmatism, Contrib. Mineral. Petrol., 160, 489-510, https://doi.org/10.1007/s00410-010-0490-6, 2010.

Bulanova, G. P., Smith, C. B., Kohn, S. C., and Speich, L.: Natural diamond growth conditions recorded by their internal structures, 11th International Kimberlite Conference, Gaborone, Botswana, 18-22 September, 11IKC-4523, 2017.

Chepurov, A. A., Dereppe, J. M., Fedorov, I. I., and Chepurov, A. I.: The change of $\mathrm{Fe}-\mathrm{Ni}$ alloy inclusions in synthetic diamond crystals due to annealing, Diam. Relat. Mater., 9, 1374-1379, https://doi.org/10.1016/S0925-9635(00)00260-0, 2000.

Chepurov, A. I., Tomilenko, A. A., Zhimulev, E. I., Sonin, V. M., Chepurov, A. A., Surkov, N. V., and Kovyazin, S. V.: Problem of water in the upper mantle: antigorite breakdown, Dokl. Earth Sci., 434, 1275-1278, https://doi.org/10.1134/S1028334X10090291, 2010.

Chepurov, A. I., Sonin, V. M., Zhimulev, E. I., Chepurov, A. A., and Tomilenko, A. A.: On the formation of element carbon during decomposition of $\mathrm{CaCO}_{3}$ at high $P-T$ parameters under reducing conditions, Dokl. Earth Sci., 441, 1738-1741, https://doi.org/10.1134/S1028334X11120233, 2011.

Chepurov, A., Sonin, V., Shcheglov, D., Latyshev, A., Filatov, E., and Yelisseyev, A.: A highly porous surface of synthetic monocrystalline diamond: Effect of etching by Fe nanoparticles in hydrogen atmosphere, Int. J. Refract. Met. H., 76, 12-15, https://doi.org/10.1016/j.ijrmhm.2018.05.011, 2018a.

Chepurov, A. I., Sonin, V. M., Zhimulev, E. I., Chepurov, A. A., Pomazansky, B. S., and Zemnukhov, A. L.: Dissolution of diamond crystals in a heterogeneous (metal-sulfide-silicate) medium at $4 \mathrm{GPa}$ and $1400^{\circ} \mathrm{C}$, J. Miner. Petrol. Sci., 113, 5967, https://doi.org/10.2465/jmps.170526, 2018 b.

Davis, W. J., Jones, A. G., Bleeker, W., and Grutter, H.: Lithosphere development in the Slave craton: a linked crustal and mantle perspective, Lithos, 71, 575-589, https://doi.org/10.1016/S00244937(03)00131-2, 2003.

Day, H. W.: A revised diamond-graphite transition curve, Am. Mineral., 97, 52-62, https://doi.org/10.2138/am.2011.3763, 2012. 
Fedorov, I. I., Chepurov, A. A., and Dereppe, J. M.: Redox conditions of metal-carbon melts and natural diamond genesis, Geochem. J., 36, 247-253, https://doi.org/10.2343/geochemj.36.247, 2002.

Fedorov, I. I., Chepurov, A. I., Chepurov, A. A., and Kuroedov, A. V.: Estimation of the rate of postcrystallization selfpurification of diamond from metal inclusions in the earth's mantle, Geochem. Int., 43, 1235-1239, 2005.

Fedorov, I. I., Chepurov, A. I., Sonin, V. M., and Zhimulev, E. I.: Experimental study of the effect of high pressure and high temperature on silicate and oxide inclusions in diamonds, Geochem. Int., 44, 1048-1052, https://doi.org/10.1134/S0016702906100107, 2006.

Field, E. J. (Eds.): The properties of natural and synthetic diamonds, Academic Press, London, 1992.

Frost, D. J. and McCammon, C. A.: The redox state of Earth's mantle, Annu. Rev. Earth Planet. Sci., 36, 389-420, https://doi.org/10.1146/annurev.earth.36.031207.124322, 2008.

Galvez, M. E., Beyssac, O., Martinez, I., Benzerara, K., Chaduteau, C., Malvoisin, B., and Malavieille, J.: Graphite formation by carbonate reduction during subduction, Nat. Geosci., 6, 473-477, https://doi.org/10.1038/NGEO1827, 2013.

Garanin, V. K. and Kudryavtseva, G. P.: Morphology, physical properties and paragenesis of inclusion-bearing diamonds from Yakutian kimberlites, Lithos, 25, 211-217, https://doi.org/10.1016/0024-4937(90)90016-T, 1990.

Giardini, A. A. and Tydings, J. E.: Diamond synthesis: Observations on the mechanism of formation, Am. Mineral., 47, 1393-1421, 1962.

Gorshkov, A. I., Yanan, B., Bershov, L. V., Ryabchikov, I. D., Sivtsov, A. V., and Lapina, M.: Inclusions in Diamond from the Liaoning Deposit (China) and Their Genetic Meaning, Geochem. Int., 35, 51-57, 1997.

Gurney, J. J.: A correlation between garnets and diamonds in kimberlites, in: Kimberlite Occurrence and origin: a Basis for Conceptual Models in Exploration, edited by: Glover, J. E. and Harris, P. G., University of Western Australia, Geology Department and Extension Service, 8, 143-166, 1984.

Gurney, J. J.: Diamonds, in: Kimberlites and related rocks, edited by: Ross, J., Blackwell, Carlton, 935-965, 1989.

Gurney, J. J., Helmstaedt, H. H., Richardson, S. H., and Shirey, S. B.: Diamonds through Time, Econ. Geol., 105, 689-712, https://doi.org/10.2113/gsecongeo.105.3.689, 2010.

Harris, J. W. and Gurney, J. J.: Inclusions in diamond, in: The properties of diamond, edited by: Field, J. E., Academic press, London, 555-591, 1979.

Harte, B.: Diamond formation in the deep mantle: the record of mineral inclusions and their distribution in relation to mantle dehydration zones, Mineral. Mag., 74, 189-215, https://doi.org/10.1180/minmag.2010.074.2.189, 2010.

Hayman, P., Kopylova, M., and Kaminsky, F.: Lower mantle diamonds from Rio Soriso (Juina area, Mato Grosso, Brazil), Contrib. Mineral. Petrol., 149, 430-445, https://doi.org/10.1007/s00410-005-0657-8, 2005.

Kadik, A., Pineau, F., Litvin, Yu., Jendrzejewski, N., Martinez, I., and Javoy, M.: Formation of Carbon and Hydrogen Species in Magmas at Low Oxygen Fugacity, J. Petrol., 45, 1297-1310, https://doi.org/10.1093/petrology/egh007, 2004.
Kagi, H., Zedgenizov, D. A., Ohfuji, H., and Ishibashi, H.: Micro- and nano-inclusions in a superdeep diamond from São Luiz, Brazil, Geochem. Int., 54, 834-838, https://doi.org/10.1134/S0016702916100062, 2016.

Kaminsky, F.: Mineralogy of the lower mantle: A review of "superdeep" mineral inclusions in diamond, Earth-Sci. Rev., 110, 127147, https://doi.org/10.1016/j.earscirev.2011.10.005, 2012.

Kaminsky, F. V. and Khachatryan, G. K.: The relationship between the distribution of nitrogen impurity centers in diamond crystals and their internal structure and mechanism of growth, Lithos, 77, 255-271, https://doi.org/10.1016/j.lithos.2004.04.035, 2004.

Kaminsky, F. V. and Wirth, R.: Iron carbide inclusions in lowermantle diamond from Juina, Brazil, Can. Mineral., 49, 555-572, https://doi.org/10.3749/canmin.49.2.555, 2011.

Kaminsky, F. V., Khachatryan, G. K., Andreazza, P., Araujo, D., and Griffin, W. L.: Super-deep diamonds from kimberlites in the Juina area, Mato Grosso State, Brazil, Lithos, 112S, 833-842, https://doi.org/10.1016/j.lithos.2009.03.036, 2009.

Kanda, H. and Oshawa, T.: Growth hillocks on the $\{111\}$ surface of high pressure synthetic diamond, Diam. Relat. Mater., 5, 8-12, https://doi.org/10.1016/0925-9635(95)00336-3, 1996.

Kanda, H., Akaishi, M., Setaka, N., Yamaoka, S., and Fukunaga, O.: Surface structures on synthetic diamonds, J. Mater. Sci., 15, 2743-2748, https://doi.org/10.1007/BF00550541, 1980.

Liu, Y., Taylor, L. A., Sarbadhikari, A. B., Valley, J. W., Ushikubo, T., Spicuzza, M. J., Kita, N., Ketcham, R. A., Carlson, W., Shatsky, V., and Sobolev, N. V.: Metasomatic origin of diamonds in the world's largest diamondiferous eclogite, Lithos, 112, 1014-1024, https://doi.org/10.1016/j.lithos.2009.06.036, 2009.

Malvoisin, B., Chopin, C., Brunet, F., and Galvez, M. E.: Lowtemperature Wollastonite Formed by Carbonate Reduction: a Marker of Serpentinite Redox Conditions, J. Petrol., 53, 159176, https://doi.org/10.1093/petrology/egr060, 2012.

Martirosyan, N. S., Yoshino, T., Shatskiy, A., Chanyshev, A. D., and Litasov, K. D.: The $\mathrm{CaCO}_{3}-\mathrm{Fe}$ interaction: kinetic approach for carbonate subduction to the deep Earth's mantle, Phys. Earth Planet. Int., 259, 1-9, https://doi.org/10.1016/j.pepi.2016.08.008, 2016.

Meyer, H. O. A. and McCallum, M. E.: Mineral inclusions in diamonds from the Sloan kimberlites, Colorado, J. Geol., 94, 600612, https://doi.org/10.1086/629062, 1986.

Mikhno, A. O. and Korsakov, A. V.: Carbonate, silicate, and sulfide melts: heterogeneity of the UHP mineral-forming media in calcsilicate rocks from the Kokchetav massif, Russ. Geol. Geophys., 56, 81-99, https://doi.org/10.1016/j.rgg.2015.01.005, 2015.

Nasdala, L., Hofmeister, W., Harris, J., and Glinnemann, J.: Growth zoning and strain patterns inside diamond crystals as revealed by Raman maps, Am. Mineral., 90, 745-748, https://doi.org/10.2138/am.2005.1690, 2005.

Nestola, F.: Inclusions in super-deep diamonds: windows on the very deep Earth, Rend. Fis. Acc. Lincei., 28, 595-604, https://doi.org/10.1007/s12210-017-0607-1, 2017.

Nestola, F., Jung, H., and Taylor, L. A.: Mineral inclusions in diamonds may be synchronous but not syngenetic, Nat. Commun., 8, 14168, https://doi.org/10.1038/ncomms14168, 2017.

Nestola, F., Korolev, N., Kopylova, M., Rotiroti, N., Pearson, D. G., Pamato, M. G., Alvaro, M., Peruzzo, L., Gurney, J. J., Moore, A. E., and Davidson, $\mathrm{J} .: \mathrm{CaSiO}_{3}$ perovskite in diamond indicates 
the recycling of oceanic crust into the lower mantle, Nature, 555, 237-241, https://doi.org/10.1038/nature25972, 2018.

Nestola, F., Jacob, D. E., Pamato, M. G., Pasqualetto, L., Oliveira, B., Greene, S., Perritt, S. H., Chinn, I., Milani, S., Kueter, N., Sgreva, N., Nimis, P., Secco, L., and Harris, J. W.: Protogenetic garnet inclusions and the age of diamonds, Geology, 47, 431434, https://doi.org/10.1130/G45781.1, 2019.

Orlov, Yu. L. (Eds.): Morphology of diamond, Acad. Sci. USSR, Moscow, 1963 (in Russian).

Palyanov, Y. N., Bataleva, Y. V., Sokol, A. G., Borzdov, Y. M., Kupriyanov, I. N., Reutsky, V. N., and Sobolev, N. V.: Mantle-slab interaction and redox mechanism of diamond formation, P. Natl. Acad. Sci. USA, 110, 20408-20413, https://doi.org/10.1073/pnas.1313340110, 2013.

Pearson, D. G., Brenker, F. E., Nestola, F., McNeill, J., Nasdala, L., Hutchison, M. T., Matveev, S., Mather, K., Silversmit, G., Schmitz, S., Vekemans, B., and Vincze, L.: Hydrous mantle transition zone indicated by ringwoodite included within diamond, Nature, 507, 221-224, https://doi.org/10.1038/nature13080, 2014.

Richardson, S. H., Gurney, J. J., Erlank, A., and Harris, J. W.: Origin of diamonds in old enriched mantle, Nature, 310, 198-202, https://doi.org/10.1038/310198a0, 1984.

Rohrbach, A., Ballhaus, C., Ulmer, P., Golla-Schindler, U., Kamenetsky, V. S., and Kuzmin, D. V.: Metal saturation in the upper mantle, Nature, 449, 456-458, https://doi.org/10.1038/nature06183, 2007.

Rohrbach, A., Ballhaus, C., Ulmer, P., Golla-Schindler, U., and Schönbohm, D.: Experimental Evidence for a Reduced Metal-saturated Upper Mantle, J. Petrol., 52, 717-731, https://doi.org/10.1093/petrology/egq101, 2011.

Scarratt, K. and Shor, R.: The Cullinan Diamond Centennial: A history and gemological analysis of Cullinans I and II, Gems Gemol., 42, 120-132, https://doi.org/10.5741/GEMS.42.2.120, 2006.

Shigley, J. E., Fritsch, E., Stocton, C. M., Koivula, J. I., Fryer, C. W., Kane, R. E., Hargett, D. R., and Welch, C. W.: The gemological properties of the De Beers gemquality synthetic yellow diamonds, Gems Gemol., 23, 187-206, https://doi.org/10.5741/GEMS.23.4.187, 1987.

Shigley, J. E., Fritsch, E., Reinitz, J., and Moon, H.: An update on Sumitomo gem-quality synthetic diamonds, Gems Gemol., 28, 116-122, https://doi.org/10.5741/GEMS.28.2.116, 1992.

Shigley, J. E., Fritsch, E., Stockton, C. M., Koivula, J. I., Fryer, C. W., and Kane, R. E.: The gemological properties of Russian gemquality synthetic yellow diamonds, Gems Gemol., 29, 228-248, https://doi.org/10.5741/GEMS.22.4.192, 1993.

Shirey, S. B. and Shigley, J. E.: Recent advances in understanding the geology of diamond, Gems Gemol., 49, 188-222, https://doi.org/10.5741/GEMS.49.4.188, 2013.

Shirey, S. B., Cartigny, P., Frost, D. J., Keshav, S., Nestola, F., Nimis, P., Pearson, D. G., Sobolev, N. V., and Walter, M. J.: Diamonds and the geology of mantle carbon, Rev. Mineral. Geochem., 75, 355-421, https://doi.org/10.2138/rmg.2013.75.12, 2013.

Smith, E. M. and Kopylova, M. G.: Implications of metallic iron for diamonds and nitrogen in the sublithospheric mantle, Can. J. Earth Sci., 51, 510-516, https://doi.org/10.1139/cjes-2013-0218, 2014.
Smith, E. M. and Wang, W.: Type IIb diamonds originate from the sublithospheric mantle, 11th International Kimberlite Conference, Gaborone, Botswana, 18-22 September, 11IKC-4502, 2017.

Smith, E. M., Shirey, S. B., Nestola, F., Bullock, E. S., Wang, J., Richardson, S. H., and Wang, W.: Large gem diamonds from metallic liquid in Earth's deep mantle, Science, 354, 1403-1405, https://doi.org/10.1126/science.aal1303, 2016.

Smith, E. M., Shirey, S. D., and Wang, W.: The very deep origin of the World's biggest diamond, Gems Gemol., 53, 388-403, https://doi.org/10.5741/GEMS.53.4.388, 2017.

Smith, E. M., Shirey, S. B., Richardson, S. H., Nestola, F., Bullock, E. S., Wang, J., and Wang, W.: Blue boron-bearing diamonds from Earth's lower mantle, Nature, 560, 84-87, https://doi.org/10.1038/s41586-018-0334-5, 2018.

Sobolev, N. V. (Eds.): Deep-seated Inclusions in Kimberlites and the Problems of the Composition of the Upper Mantle, Am. Geophys. Union, Washington, 1977.

Sobolev, N. V., Lavrent'ev, Y. G., Pokhilenko, N. P., and Usova, N. P.: Chrome-rich garnets of Yakutia and their parageneses, Contrib. Mineral. Petrol., 40, 39-52, 1973.

Sobolev, N. V., Efimova, E. S., and Pospelova, L. N.: Native iron in Yakutian diamonds and its paragenesis, Geologia i Geofizika, 12, 25-29, 1981 (in Russian).

Sobolev, N. V., Logvinova, A. M., Zedgenizov, D. A., Seryotkin, Y. V., Yefimova, E. S., Floss, C., and Taylor, L. A.: Mineral inclusions in microdiamonds and macrodiamonds from kimberlites of Yakutia: a comparative study, Lithos, 77, 225-242, https://doi.org/10.1016/j.lithos.2004.04.001, 2004.

Stachel, T.: Diamonds from the asthenosphere and the transition zone, Eur. J. Mineral., 13, 883-892, https://doi.org/10.1127/0935-1221/2001/0013/0883, 2001.

Stachel, T. and Harris, J. W.: The origin of cratonic diamonds constraints from mineral inclusions, Ore Geol. Rev., 34, 5-32, https://doi.org/10.1016/j.oregeorev.2007.05.002, 2008.

Stachel, T., Harris, J. W., and Brey, G. P.: Rare and unusual mineral inclusions in diamond from Mwadui, Tanzania, Contrib. Mineral. Petrol., 132, 34-47, https://doi.org/10.1007/s004100050403, 1998.

Stachel, T., Brey, G. P., and Harris, J. W.: Inclusions in sublithospheric diamonds: Glimpses of deep Earth, Elements, 1, 73-78, https://doi.org/10.2113/gselements.1.2.73, 2005.

Sunagava, I., Tsukamoto, K., and Yasuda, T.: Surface micrographic and X-ray topographic study of octahedral crystals of natural diamond from Siberia, in: Materials Science of the Earth's Interior, edited by: Sunagava I., TERRABUB, Tokyo, 331-349, 1984.

Thomson, A. R., Kohn, S. C., Bulanova, G. P., Smith, C. B., Araujo, D., and Walter, M. J.: Origin of sub-lithospheric diamonds from the Juina-5 kimberlite (Brazil): constraints from carbon isotopes and inclusion compositions, Contrib. Mineral. Petrol., 168, 1081, https://doi.org/10.1007/s00410-014-1081-8, 2014.

Tolansky, S.: Synthetic diamonds: growth and etch phenomena, Proc. R. Soc. London, 270, 443-451, https://doi.org/10.1098/rspa.1962.0236, 1962.

Tomilenko, A. A., Chepurov, A. I., Sonin, V. M., Bul‘bak, T. A., Zhimulev, E.I., Chepurov, A. A., Timina, T. Yu., and Pokhilenko, N. P.: The synthesis of methane and heavier hydrocarbons in the system graphite-iron-serpentine at 2 and $4 \mathrm{GPa}$ and $1200^{\circ} \mathrm{C}$, High Temp.-High Press., 44, 451-465, 2015. 
Tonkov, E. Yu. and Ponyatovsky, E. G. (Eds.): Phase transformation of elements under high pressure, CRC Press, 2004.

Turkin, A. I.: Lead selenide as a continuous internal indicator of pressure in solid-media cells of high-pressure apparatus in the range of 4-6.8 GPa, High Temp.-High Press., 35/36, 371-376, 2003/2004.

Van Enckevort, W. J. P.: Phase shifting interferometry of growth patterns on the octahedral faces of natural diamond, J. Cryst. Growth, 119, 177-194, https://doi.org/10.1016/00220248(92)90670-E, 1992.

Vinokurov, S. F., Gorshkov, A. I., Bao, Y. N., Ryabchikov, I. D., Bershov, L. V., and Lapina, M.: Diamonds from Kimberlite Diatreme 50, Liaoning Province, China: Microtextural, Mineralogical, Geochemical, and Genetic Characteristics, Geochem. Int., 36, 676-683, 1998 (in Russian with English abstract).

Walte, J., Rubie, D. C., Bons, P. D., and Frost, D. J.: Deformation of a crystalline aggregate with a small percentage of high-dihedralangle liquid: Implications for core-mantle differentiation during planetary formation, Earth Planet. Sci. Lett., 305, 124-134, https://doi.org/10.1016/j.epsl.2011.02.049, 2011.

Win, T. T., Davies, R. M., Griffin, W. L., Wathanakhul, P., and Frenc, D. H.: Distribution and characteristics of diamonds from Myanmar, J. Asian Earth Sci., 19, 563-577, https://doi.org/10.1016/S1367-9120(00)00055-9, 2001.
Yoshino, T., Walter, M. J., and Katsura, T.: Connectivity of molten $\mathrm{Fe}$ alloy in peridotite based on in situ electrical conductivity measurements: implications for core formation in terrestrial planets, Earth Planet. Sci. Lett., 222, 625-643, https://doi.org/10.1016/j.epsl.2004.03.010, 2004.

Zedgenizov, D. A., Ragozin, A., Kalinina, V. V., and Kagi, H.: The mineralogy of Ca-rich inclusions in sublithospheric diamonds, Geochem. Int., 54, 890-900, https://doi.org/10.1134/S0016702916100116, 2016.

Zhimulev, E. I., Chepurov, A. I., Sinyakova, E. F., Sonin, V. M., Chepurov, A. A., and Pokhilenko, N. P.: Diamond crystallization in the Fe-Co-S-C and Fe-Ni-S-C systems and the role of sulfidemetal melts in the genesis of diamond, Geochem. Int., 50, 205216, https://doi.org/10.1134/S0016702912030111, 2012.

Zhimulev, E. I., Sonin, V. M., Bul'bak, T. A., Chepurov, A. I., Tomilenko, A. A., and Pokhilenko, N. P.: Volatile compounds of sulfur in the Fe-S-C system at $5.3 \mathrm{GPa}$ and $1300^{\circ} \mathrm{C}$, Dokl. Earth Sci., 462, 527-532, https://doi.org/10.1134/S1028334X15050219, 2015.

Zhimulev, E. I., Chepurov, A. I., Sonin, V. M., Litasov, K. D., and Chepurov, A. A.: Experimental modeling of percolation of molten iron through polycrystalline olivine matrix at 2.0-5.5 GPa and $1600^{\circ} \mathrm{C}$, High Pressure Res., 38, 153-164, https://doi.org/10.1080/08957959.2018.1458847, 2018. 